Provided for non-commercial research and education use. Not for reproduction, distribution or commercial use.

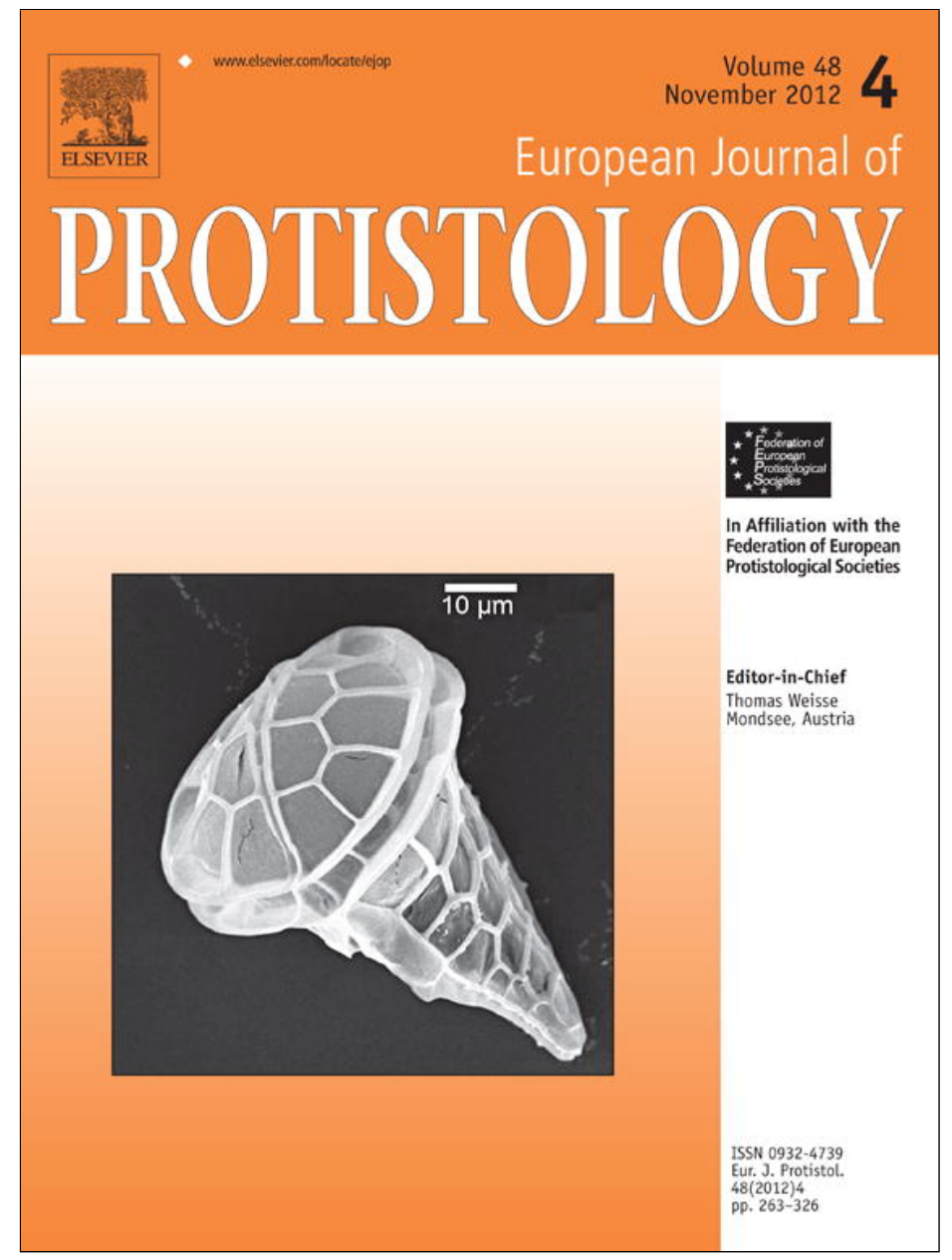

This article appeared in a journal published by Elsevier. The attached copy is furnished to the author for internal non-commercial research and education use, including for instruction at the authors institution and sharing with colleagues.

Other uses, including reproduction and distribution, or selling or licensing copies, or posting to personal, institutional or third party websites are prohibited.

In most cases authors are permitted to post their version of the article (e.g. in Word or Tex form) to their personal website or institutional repository. Authors requiring further information regarding Elsevier's archiving and manuscript policies are encouraged to visit:

http://www.elsevier.com/copyright 


\title{
Redescriptions of three tintinnid ciliates, Tintinnopsis tocantinensis, T. radix, and T. cylindrica (Ciliophora, Spirotrichea), from coastal waters off China
}

\author{
Yong Jiang ${ }^{\mathrm{a}, \mathrm{b}, \mathrm{c}}$, Jinpeng Yang ${ }^{\mathrm{b}, \mathrm{c}}$, Saleh A. Al-Farraj ${ }^{\mathrm{d}}$, Alan Warren ${ }^{\mathrm{e}}$, Xiaofeng Lin ${ }^{\mathrm{a}, *}$ \\ ${ }^{a}$ Laboratory of Protozoology, Key Laboratory of Ecology and Environmental Science in Guangdong Higher Education, College of Life Science, \\ South China Normal University, Guangzhou 510631, China \\ ${ }^{\mathrm{b}}$ Laboratory of Protozoology, Institute of Evolution and Marine Biodiversity, Ocean University of China, Qingdao 266003, China \\ ${ }^{\mathrm{c}}$ Alfred Wegener Institute for Polar and Marine Research, Helgoland 27498, Germany \\ ${ }^{\mathrm{d}}$ Zoology Department, King Saud University, Riyadh 11451, Saudi Arabia \\ ${ }^{\mathrm{e}}$ Department of Zoology, Natural History Museum, London SW7 5BD, UK
}

Received 12 October 2011; received in revised form 5 February 2012; accepted 13 February 2012 Available online 16 March 2012

\begin{abstract}
In the present study the morphology and ciliary pattern of three marine tintinnid ciliates, namely Tintinnopsis tocantinensis Kofoid and Campbell, 1929, Tintinnopsis radix (Imhof, 1886) Brandt, 1907, and Tintinnopsis cylindrica Daday, 1887, isolated from Chinese coastal waters off Shenzhen and Qingdao, respectively, were investigated using living observation and silver impregnation methods. Detailed ciliary patterns of $T$. tocantinensis and $T$. radix are reported here for the first time, comprising a ventral, dorsal, and posterior kinety as well as a right, left, and lateral ciliary field. Furthermore, based on previous and present investigations, redescriptions for all three species and improved diagnoses for T. tocantinensis and T. radix are supplied. (C) 2012 Elsevier GmbH. All rights reserved.
\end{abstract}

Keywords: Biodiversity; Ciliary pattern; Oligotricha; Plankton; Taxonomy; Tintinnids

\section{Introduction}

Oligotrichs (s.1.) are one of the most common groups of planktonic ciliates, inhabiting in both marine and fresh waters (e.g., Agatha 2011; Gao et al. 2009; Foissner and Wilbert 1979; Kim et al. 2010; Liu et al. 2009, 2011a,b; McManus et al. 2010; Tsai et al. 2010; Zhang et al. 2010). Considering the pathway of energy and materials, they are important elements of the planktonic food web (Choi et al. 1992; Dolan 1991; Jiang et al. 2011a,b; Pierce and Turner 1992, 1993, 1994). Marine tintinnids are characterized by their highly

\footnotetext{
*Corresponding author. Tel.: +86 20 85210644; fax: +86 2085210644 .

E-mail address: xlin@scnu.edu.cn (X. Lin).
}

specialized rigid lorica, and are one of the most common groups of oligotrichs in marine plankton (Agatha and RiedelLorjé 2006; Cosper 1972; Kofoid and Campbell 1929, 1939; Laackmann 1913; Petz et al. 1995; Rychert 2010).

Tintinnids comprise 1200 or so morphospecies (Agatha 2010a; Agatha and Riedel-Lorjé 2006; Agatha and Tsai 2008) and the genus Tintinnopsis Stein, 1867 includes about 190 species (Agatha 2008). The majority of these are known only from their lorica characters, e.g., shape, size and structure (Agatha 2010a,b; Agatha and Riedel-Lorjé 2006; Kofoid and Campbell 1929, 1939; Laval-Peuto 1994). To date, cell features have been reported for only about 20 tintinnid species (e.g., Agatha 2008, 2010a; Agatha and Riedel-Lorjé 2006; Agatha and Tsai 2008; Petz et al. 1995). Therefore, large gaps still persist in our knowledge of tintinnids. 
During surveys on ciliate fauna in costal regions of Chinese seas, three tintinnid ciliates were collected, namely Tintinnopsis tocantinensis, $T$. radix, and $T$. cylindrica. Tintinnopsis cylindrica has been recently redescribed based on a German population, including details of its cell morphology (Agatha and Riedel-Lorjé 2006). Tintinnopsis tocantinensis and $T$. radix are known only from their lorica (Balech 1948, 1959; Dolan 1991). The knowledge of their ciliary pattern and living morphology is still inadequate. In the present study, we examined specimens of all three species both in vivo and following protargol impregnation. A morphological redescription and an improved diagnosis are supplied for each.

\section{Material and Methods}

Surface water samples containing Tintinnopsis tocantinensis were collected with a plankton net (mesh size $20 \mu \mathrm{m}$ ) from Daya Bay $\left(22^{\circ} 37^{\prime} \mathrm{N} 114^{\circ} 04^{\prime} \mathrm{E}\right)$, near Shenzhen, southern China, on 9th December 2008. Tintinnopsis radix and $T$. cylindrica were collected from the surface water in Jiaozhou Bay $\left(36^{\circ} 03^{\prime} \mathrm{N} 120^{\circ} 21^{\prime} \mathrm{E}\right)$, near Qingdao, northern China, on 29th April 2007 and 7th September 2007, respectively.

Specimens were isolated in the laboratory and observed in vivo. The protargol impregnation followed the protocol of Song and Wilbert (1995). Counts and measurements on protargol-impregnated cells were performed at a magnification of $1000 \times$, while in vivo measurements were made at magnifications of $40-1000 \times$. Drawings of protargolimpregnated specimens were made with the help of a camera lucida. Terminology is mainly according to Agatha and Riedel-Lorjé (2006) and systematics according to Lynn (2008).

\section{Results and Discussion}

\section{Tintinnopsis tocantinensis Kofoid and Campbell, 1929 (Figs 1A-K, 2A-E; Table 1)}

\section{Improved diagnosis}

Lorica $85-160 \mu \mathrm{m}$ long and $15-45 \mu \mathrm{m}$ wide. Bulbous part ovoid, 30-65 $\mu \mathrm{m}$ wide, tapered portion $15-50 \mu \mathrm{m}$ long. Extended cell $40-70 \mu \mathrm{m} \times 20-40 \mu \mathrm{m}$ in vivo, elongate obconical. Two macronuclear nodules and two micronuclei. Ventral kinety commences anteriorly to second kinety of right ciliary field. About nine kineties each in right and left ciliary fields, all composed of monokinetids and one anterior dikinetid. Lateral ciliary field with about nine monokinetidal kineties. On average 32 dikinetids in dorsal kinety and 11 in posterior kinety. About 22 collar membranelles, three of which extend into buccal cavity; one buccal membranelle; endoral membrane long.

\section{Deposition of voucher slides}

Two voucher slides (Nos. JY0812090301 and JY0812090302) with protargol-impregnated specimens are deposited in the Laboratory of Protozoology, Institute of Evolution and Marine Biodiversity, Ocean University of China. A third voucher slide with protargol-impregnated specimens is deposited in the Natural History Museum, London, UK with Registration No. NHMUK 2011.8.25.1.

\section{Description of Daya Bay population}

Lorica tripartite, that is, composed of a cylindroidal portion, a bulbous part, and a tapered portion; 112-160 $\mu \mathrm{m}$ long. Aperture 17-44 $\mu \mathrm{m}$ in diameter. Bulbous part ovoidal, 32-64 $\mu \mathrm{m}$ wide, occupying about $30 \%$ of lorica length. Cylindroidal part as wide as aperture, 40-80 $\mu \mathrm{m}$ long. Posterior tapered portion stout, 16-48 $\mu \mathrm{m}$ long, usually open at rear end (Figs 1A, B, 2A, B; Table 1). Wall of lorica densely covered with field material, rigid, about $2 \mu \mathrm{m}$ thick, without spiralled or annulated structures. Agglomerated particles of abiotic and, rarely biotic (e.g., diatom frustules and their fragments) origin (Fig. 1C).

Fully extended cell $40-70 \mu \mathrm{m} \times 20-40 \mu \mathrm{m}$ in vivo, elongate obconical, i.e. cell proper gradually merges ventrolaterally into slender, wrinkled, and highly contractile stalk; stalk up to $60 \mu \mathrm{m}$ long, attached to transition zone between lorica bowl and posterior process (Figs 1A, 2A). Two ellipsoidal macronuclear nodules, one each in anterior and posterior halves of cell, with several large (about $4 \mu \mathrm{m}$ across) and small (1-2 $\mu \mathrm{m}$ across) dark inclusions, probably nucleoli (Fig. 1E). Two globular micronuclei, one adjacent to each macronuclear nodule, difficult to recognize because usually only faintly impregnated with protargol. Neither contractile vacuole nor cytopyge recognized. Accessory combs, striae, tentaculoids, and capsules not recognized. Cytoplasm colourless, containing food vacuoles up to $8 \mu \mathrm{m}$ in diameter. Swims rapidly while rotating about main cell axis, reversing rapidly on collision with an obstacle. If disturbed, cells retracting quickly into lorica, with motionless membranelles bending towards centre of peristomial field. Eventually cells slowly extending out of lorica aperture spreading collar membranelles almost perpendicularly to main cell axis, and resume swimming and feeding (Fig. 1B). Lorica abandonment never observed.

Somatic ciliary pattern typical of genus (Agatha and Strüder-Kypke 2007), i.e. comprising ventral, dorsal, and posterior kineties as well as right, left, and lateral ciliary fields (Figs 1G, H, J, K, 2C-E). Length of kineties and number of kinetids usually highly variable. Ventral kinety commencing about $5 \mu \mathrm{m}$ behind collar membranelles, curving slightly leftwards, extending in parallel to kineties of lateral ciliary field, composed of densely spaced monokinetids in anterior portion but more widely ones in posterior portion; cilia increase in length from about $3 \mu \mathrm{m}$ in anterior portion to 5-6 $\mu \mathrm{m}$ in posterior (Figs $1 \mathrm{~J}, 2 \mathrm{C}, \mathrm{E}$ ). Dikinetidal dorsal kinety commencing $1-2 \mu \mathrm{m}$ posterior to collar membranelles, about $10 \mu \mathrm{m}$ from left and $20 \mu \mathrm{m}$ from right 
Table 1. Morphometric data of Tintinnopsis tocantinensis (line 1), T. radix (line 2), and T. cylindrica (line 3).

\begin{tabular}{|c|c|c|c|c|c|c|c|}
\hline Characteristic $^{\mathrm{a}}$ & Min & Max & Mean & SD & SE & $\mathrm{CV}$ & $n$ \\
\hline \multirow[t]{3}{*}{ Lorica, total length } & 112 & 160 & 136.2 & 17.0 & 4.0 & 12.5 & 18 \\
\hline & 192 & 336 & 227.8 & 45.0 & 14.99 & 19.7 & 9 \\
\hline & 136 & 178 & 160.3 & 11.0 & 2.54 & 6.8 & 20 \\
\hline \multirow[t]{3}{*}{ Lorica, aperture diameter } & 17 & 44 & 32.9 & 7.6 & 1.79 & 23.1 & 18 \\
\hline & 36 & 72 & 54.3 & 9.2 & 3.08 & 17.0 & 9 \\
\hline & 48 & 52 & 49.7 & 1.6 & 0.36 & 3.3 & 20 \\
\hline \multirow[t]{3}{*}{ Lorica, length of cylindroidal portion } & 40 & 80 & 62.7 & 10.7 & 2.53 & 17.1 & 18 \\
\hline & 80 & 192 & 125.3 & 36.5 & 12.17 & 29.1 & 9 \\
\hline & 91 & 132 & 116.2 & 10.1 & 2.25 & 8.7 & 20 \\
\hline \multirow[t]{3}{*}{ Lorica, length of tapered portion } & 16 & 48 & 31.1 & 6.9 & 1.63 & 22.3 & 18 \\
\hline & 80 & 144 & 104.7 & 23.0 & 7.67 & 22.0 & 9 \\
\hline & 36 & 52 & 44.1 & 4.6 & 1.04 & 10.5 & 20 \\
\hline \multirow[t]{3}{*}{ Lorica, diameter of bulbous part } & 32 & 64 & 51.0 & 10.2 & 2.41 & 20.1 & 18 \\
\hline & - & - & - & - & - & - & - \\
\hline & - & - & - & - & - & - & - \\
\hline \multirow[t]{3}{*}{ Cell, length } & 40 & 72 & 53.6 & 9.5 & 2.18 & 17.7 & 19 \\
\hline & 56 & 100 & 81.3 & 14.1 & 4.71 & 17.4 & 9 \\
\hline & 56 & 112 & 85.4 & 15.6 & 3.50 & 18.3 & 20 \\
\hline \multirow[t]{3}{*}{ Cell, width } & 20 & 40 & 28.5 & 6.0 & 1.38 & 21.0 & 19 \\
\hline & 37 & 60 & 45.1 & 7.0 & 2.34 & 15.6 & 9 \\
\hline & 36 & 42 & 40.2 & 1.3 & 0.29 & 3.2 & 20 \\
\hline \multirow[t]{3}{*}{ Macronuclear nodule, length } & 8 & 25 & 16.7 & 4.4 & 0.71 & 26.3 & 19 \\
\hline & 8 & 20 & 13.5 & 2.8 & 0.67 & 21.0 & 9 \\
\hline & 8 & 22 & 16.7 & 3.1 & 0.49 & 18.6 & 20 \\
\hline \multirow[t]{3}{*}{ Macronuclear nodule, width } & 4 & 12 & 8.5 & 2.0 & 0.33 & 24.0 & 19 \\
\hline & 5 & 12 & 9.6 & 2.1 & 0.49 & 21.8 & 9 \\
\hline & 8 & 15 & 10.4 & 2.1 & 0.34 & 20.5 & 20 \\
\hline \multirow[t]{3}{*}{ Macronuclear nodule, number } & 2 & 2 & 2.0 & 0 & 0 & 0 & 19 \\
\hline & 2 & 2 & 2.0 & 0 & 0 & 0 & 9 \\
\hline & 2 & 2 & 2.0 & 0 & 0 & 0 & 20 \\
\hline \multirow[t]{3}{*}{ Micronuclei, number } & 2 & 2 & 2.0 & 0 & 0 & 0 & 10 \\
\hline & 2 & 2 & 2.0 & 0 & 0 & 0 & 6 \\
\hline & 1 & 3 & 2.0 & 0.5 & 0.10 & 22.9 & 20 \\
\hline \multirow[t]{3}{*}{ Ventral kinety, length } & 18 & 48 & 30.9 & 8.6 & 2.08 & 27.7 & 17 \\
\hline & 32 & 48 & 37.0 & 5.6 & 1.96 & 15.0 & 8 \\
\hline & 32 & 64 & 47.2 & 9.4 & 2.97 & 19.9 & 10 \\
\hline \multirow[t]{3}{*}{ Ventral kinety, number of kinetids } & 17 & 42 & 29.2 & 6.8 & 1.64 & 23.1 & 17 \\
\hline & 34 & 68 & 47.8 & 10.4 & 3.68 & 21.8 & 8 \\
\hline & 44 & 67 & 53.8 & 8.4 & 2.64 & 15.5 & 10 \\
\hline \multirow[t]{3}{*}{ Dorsal kinety, length } & 32 & 64 & 45.0 & 8.6 & 2.03 & 19.2 & 18 \\
\hline & 44 & 88 & 68.3 & 14.8 & 5.22 & 21.6 & 8 \\
\hline & 48 & 88 & 69.4 & 11.5 & 3.65 & 16.6 & 10 \\
\hline \multirow[t]{3}{*}{ Dorsal kinety, number of kinetids } & 17 & 55 & 32.2 & 10.1 & 2.39 & 31.4 & 18 \\
\hline & 40 & 70 & 56.1 & 8.9 & 3.15 & 15.9 & 8 \\
\hline & 30 & 56 & 39.2 & 9.0 & 2.84 & 22.9 & 10 \\
\hline \multirow[t]{3}{*}{ Posterior kinety, length } & 12 & 24 & 17.2 & 4.8 & 1.17 & 28.1 & 17 \\
\hline & 22 & 56 & 43.8 & 11.0 & 3.90 & 25.2 & 8 \\
\hline & 16 & 36 & 25.7 & 6.0 & 1.90 & 23.3 & 10 \\
\hline Posterior kinety, number of kinetids & 7 & 18 & 10.8 & 2.7 & 0.66 & 25.3 & 17 \\
\hline & 16 & 28 & 20.6 & 4.0 & 1.41 & 19.4 & 8 \\
\hline & 10 & 19 & 16.4 & 2.5 & 0.81 & 15.5 & 10 \\
\hline Left ciliary field, number of kineties & 8 & 10 & 8.9 & 0.7 & 0.16 & 7.8 & 17 \\
\hline & 12 & 14 & 12.5 & 0.9 & 0.32 & 7.4 & 8 \\
\hline & 11 & 12 & 11.6 & 0.5 & 0.16 & 4.5 & 10 \\
\hline Lateral ciliary field, number of kineties & 8 & 11 & 9.0 & 0.8 & 0.20 & 9.1 & 16 \\
\hline & 19 & 24 & 20.1 & 1.6 & 0.58 & 8.2 & 8 \\
\hline & 13 & 16 & 14.9 & 1.4 & 0.43 & 9.2 & 10 \\
\hline
\end{tabular}


Table 1 (Continued)

\begin{tabular}{lcccccrr}
\hline Characteristic $^{\text {a }}$ & Min & Max & Mean & SD & SE & CV & $n$ \\
\hline Right ciliary field, number of kineties & 6 & 8 & 7.0 & 0.4 & 0.09 & 5.1 & 17 \\
& 12 & 14 & 12.3 & 0.7 & 0.25 & 5.8 & 8 \\
Collar membranelles, number & 10 & 12 & 10.7 & 0.7 & 0.21 & 6.3 & 10 \\
& 20 & 24 & 22.3 & 0.9 & 0.20 & 3.9 & 19 \\
Prolonged collar membranelles, number & 18 & 20 & 19.0 & 0.7 & 0.24 & 3.7 & 9 \\
& 19 & 22 & 19.5 & 1.1 & 0.38 & 5.5 & 8 \\
Buccal membranelles, number & 3 & 3 & 3.0 & 0 & 0 & 0 & 19 \\
& 4 & 5 & 5.0 & 0 & 0 & 0 & 9 \\
& 1 & 4 & 4 & 0 & 0 & 0 & 20 \\
& 1 & 1 & 1.0 & 0 & 0 & 0 & 19 \\
& 1 & 1 & 1.0 & 0 & 0 & 0 & 9 \\
\hline
\end{tabular}

${ }^{a}$ Measurements in $\mu \mathrm{m}$. CV, coefficient of variation in \%; Min, minimum; Max, maximum; Mean, arithmetic mean; $n$, number of individuals investigated; $\mathrm{SD}$, standard deviation.

ciliary fields respectively, and extending to posterior end of cell; cilia about $7 \mu \mathrm{m}$ long and only at each posterior dikinetidal basal body (Figs 1G, H, K, 2D). Posterior kinety dikinetidal, commencing close to posterior end of ventral kinety and curving leftwards to posterior end of cell; cilia 6-7 $\mu \mathrm{m}$ long and only at each posterior dikinetidal basal body (Figs 1I, 2D, E). Kineties of right ciliary field commencing about $8 \mu \mathrm{m}$ behind collar membranelles, composed of widely
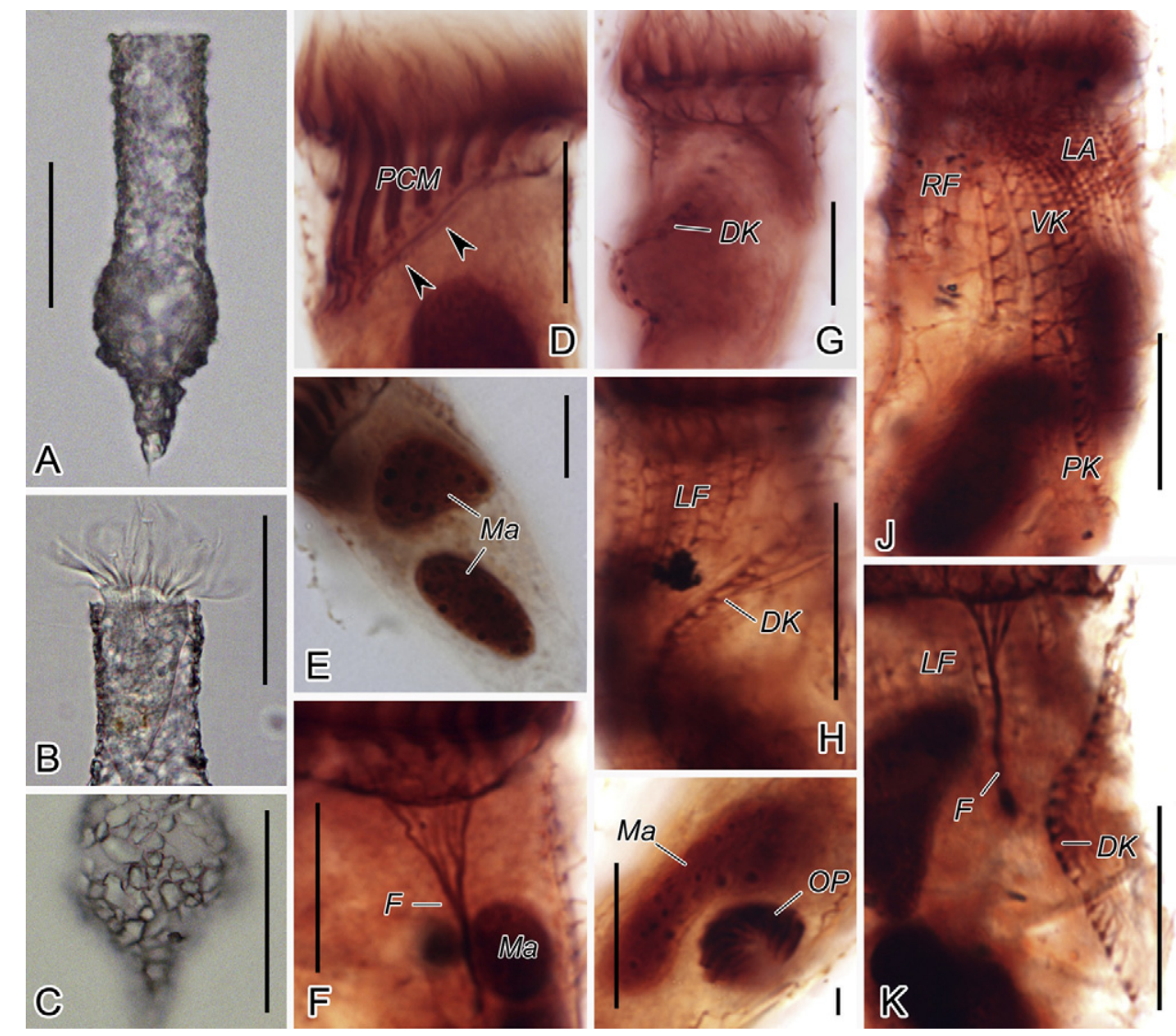

Fig. 1. A-K. Tintinnopsis tocantinensis from life (A-C) and after protargol impregnation (D-K). A. Typical lorica, lateral view. B. Showing oral cilia extending through lorica aperture. C. Lorica wall with many mineral particles. D. Oral zone, arrowheads show the fibres accompanying the distal ends of the collar membranelles. E. Macronuclear nodules. F. Fibres. G-K. Ciliary pattern of dorsal side. I. Oral primordium of the opisthe. J. Ciliary pattern of ventral side, arrows mark the ventral kinety and arrowheads show the posterior kinety. DK, dorsal kinety; F, fibrillar structures; LA, lateral ciliary field; LF, left ciliary field; Ma, macronuclear nodules; OP, oral primordium; PCM, prolonged collar membranelles; PK, posterior kinety; RF, right ciliary field; VK, ventral kinety. Scale bars $=50 \mu \mathrm{m}(\mathrm{A}-\mathrm{C}) ; 20 \mu \mathrm{m}(\mathrm{D}-\mathrm{K})$. 


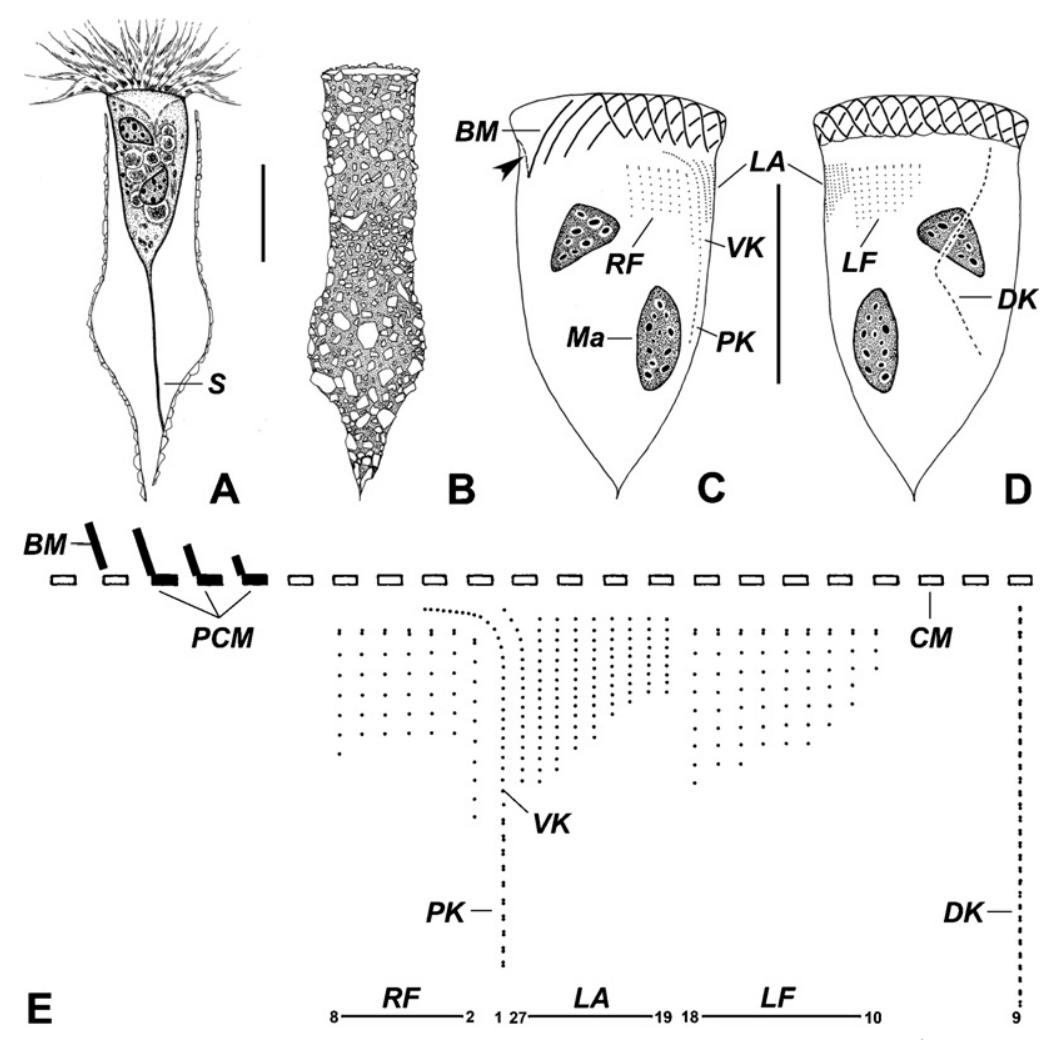

Fig. 2. A-E. Tintinnopsis tocantinensis from life (A, B) and after protargol impregnation (C-E). A. Lateral view of a typical individual. B. Lorica with agglomerated mineral particles. C, D. Ciliary pattern of ventral (C) and dorsal (D) side, arrowhead marks the endoral membrane. E. Kinetal map of a morphostatic specimen. BM, buccal membranelle; CM, collar membranelles; DK, dorsal kinety; LA, lateral ciliary field; LF, left ciliary field; Ma, macronuclear nodule; Mi, micronucleus; PCM, prolonged collar membranelles; PK, posterior kinety; RF, right ciliary field; S, stalk; VK, ventral kinety. Scale bars $=50 \mu \mathrm{m}$.

spaced monokinetids and one anterior dikinetid; cilia 5-6 $\mu \mathrm{m}$ long, except for the $9-10 \mu \mathrm{m}$ long anteriormost dikinetidal cilia (Figs 1J, 2C, E). Kineties of left ciliary field commencing about $5 \mu \mathrm{m}$ behind collar membranelles, composed of widely spaced monokinetids with one anterior dikinetid, their length increasing in clockwise direction when viewed from apical aspect; cilia 3-4 $\mu \mathrm{m}$ long, except for the 7-9 $\mu \mathrm{m}$ long anteriormost dikinetidal cilia (Figs 1H, 2D). Lateral ciliary field with about nine monokinetidal kineties, composed of closely spaced monokinetids with cilia about $2 \mu \mathrm{m}$ long. The last kinety extending parallel to the distinctly curved ventral kinety (Figs 1J, 2C-E). An argyrophilic structure, probably fibrillar, originating in circular fibres below collar membranelles, extending longitudinally posteriorly and connecting kinetids in ciliary rows and parallelling to cell surface (Fig. 1F, K).

Oral apparatus occupying anterior cell portion. Adoral zone of membranelles closed, lying orthogonally to main cell axis, consisting of 20-24 collar membranelles with cilia up to 25-30 $\mu \mathrm{m}$ long (Figs 1B, 2A, D, E), including three that are significantly prolonged and a single buccal membranelle (Figs 1D, 2C). Endoral membrane composed of a single row of monokinetids, extends across peristomial field and right wall of buccal cavity (Fig. 2C).

\section{Cell division}

Enantiotropic division with hypoapokinetal formation of the oral primordium in a subsurface pouch left of ventral kinety and posterior to the lateral ciliary field (Fig. 1I). Adoral membranelles immediately beginning to differentiate within this cuneate field of basal bodies. Each macronuclear nodule has a replication band. Lorica formation not observed.

\section{Ecological features of Daya Bay population}

Water temperature $17.7^{\circ} \mathrm{C}$, salinity $30.4 \%$, $\mathrm{pH} 8.5$.

\section{Morphological comparison and remarks}

Tintinnopsis tocantinensis is a widely distributed species that has been well-documented (e.g., Balech 1948; Dolan 1991; Zhang and Wang 2000). We identified this Chinese population based on the lorica features. It agrees well with the original population described by Brandt (1906, 1907); (as T. aperta var. a) for which Kofoid and Campbell (1929) established T. tocantinensis in lorica appearance, thus both can be regarded as conspecific. The lorica shape of our isolate matches that of type population (Brandt 1906, 1907) very well, although it is considerably longer $(112-160 \mu \mathrm{m}$ vs. $85 \mu \mathrm{m})$. It differs from T. aperta Brandt, 1906, 1907 in shorter lorica length $(112-160 \mu \mathrm{m}$ vs. $130-300 \mu \mathrm{m})$, 


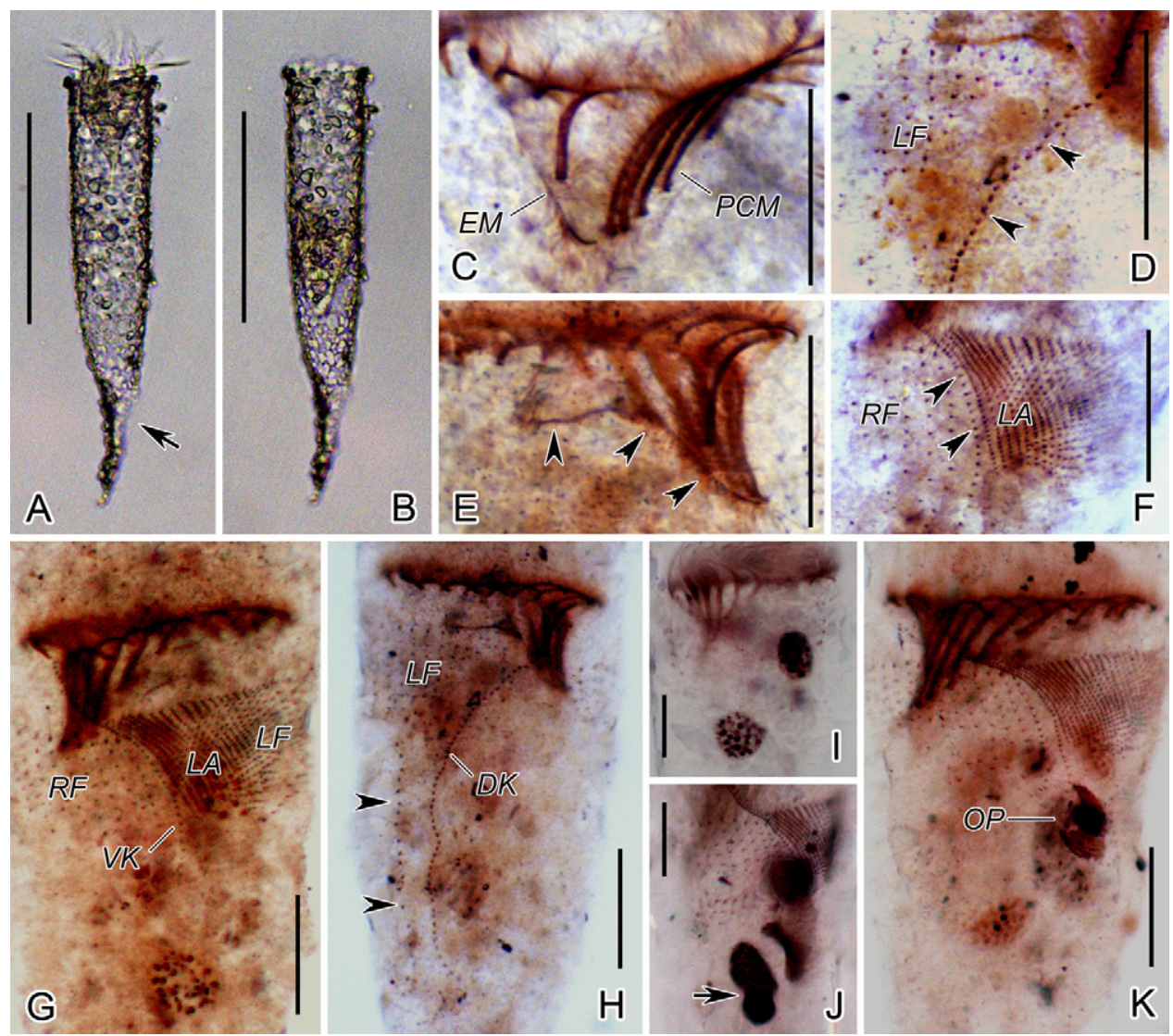

Fig. 3. A-K. Tintinnopsis radix from life (A, B) and after protargol impregnation (C-K). A. Lateral view showing the cylindroidal lorica and an extended cell, arrow marks the gap in the tapered portion. B. Lorica with contracted cell. C, E. Oral zone, arrowheads denote the endoral membrane. D. Dorsal view, arrowheads indicate the dorsal kinety. F, G. Ciliary pattern of ventral side, arrowheads show the ventral kinety. H. Ciliary pattern of dorsal side, arrowheads show the posterior kinety. I. Macronuclear nodules. J, K. Ventral view of dividers, arrow shows the reorganization band of a macronuclear nodule. DK, dorsal kinety; EM, endoral membrane; LA, lateral ciliary field; LF, left ciliary field; OP, oral primordium; PCM, prolonged collar membranelles; RF, right ciliary field; VK, ventral kinety. Scale bars $=150 \mu \mathrm{m}(\mathrm{A}, \mathrm{B}) ; 20 \mu \mathrm{m}(\mathrm{C}-\mathrm{K})$.

longer bulbous part and stouter tapered portion (e.g., Brandt 1906, 1907; Balech 1948). Furthermore, the lorica size of our population falls well within the range of most other populations (e.g., Balech 1948; Cosper 1972; Paulmier 1997; Xu and Song 2005), i.e. length 85-160 $\mu \mathrm{m}$, aperture $15-45 \mu \mathrm{m}$ in diameter, bulbous part $30-65 \mu \mathrm{m}$ in diameter, cylindroidal portion length $40-80 \mu \mathrm{m}$ and posterior tapered portion length $15-50 \mu \mathrm{m}$. The similarity with the northern China population of $\mathrm{Xu}$ and Song (2005) is particularly strong. Hence, the identity of our population is not in doubt. Additionally, we supply an improved diagnosis.

Cell features for Tintinnopsis species have been rarely investigated. Nevertheless, the somatic ciliary pattern and oral apparatus of $T$. tocantinensis were found to be similar to those in Tintinnopsis cylindrata (Foissner and Wilbert 1979), T. cylindrica (Agatha and Riedel-Lorjé 2006), T. fimbriata (Agatha 2008) and T. parvula (Agatha 2010a) with collar membranelles (including prolonged collar membranelles), one buccal membranelle, a ventral, dorsal, and posterior kinety as well as a right, left, and lateral ciliary fields.
Ontogenesis has been partially studied after protargol impregnation at least in seven species of tintinnids, namely Codonella cratera (Petz and Foissner 1993), Cymatocylis convallaria (Petz et al. 1995), Favella sp. (Laval-Peuto 1994), Stenosemella pacifica (Agatha and Tsai 2008), Tintinnopsis cylindrica (Agatha and Riedel-Lorjé 2006), T. fimbriata (Agatha 2008), and T. parvula (Agatha 2010a). Tintinnopsis tocantinensis is consistent with all these in that the oral primordium is located posterior to the lateral ciliary field. The posterior kinety curves along the lower right margin of the oral primordium.

\section{Tintinnopsis radix (Imhof, 1886) Brandt, 1907 (Figs 3A-K, 4A-E; Table 1)}

\section{Improved diagnosis}

Lorica $190-524 \mu \mathrm{m}$ long, aperture $35-72 \mu \mathrm{m}$ in diameter, elongated, narrowing gradually to pedicel with opening near tip, wall thin and agglomerated. Cell elongate-obconical and highly contractile. Two macronuclear nodules and two micronuclei. Ventral kinety commencing anterior to second 


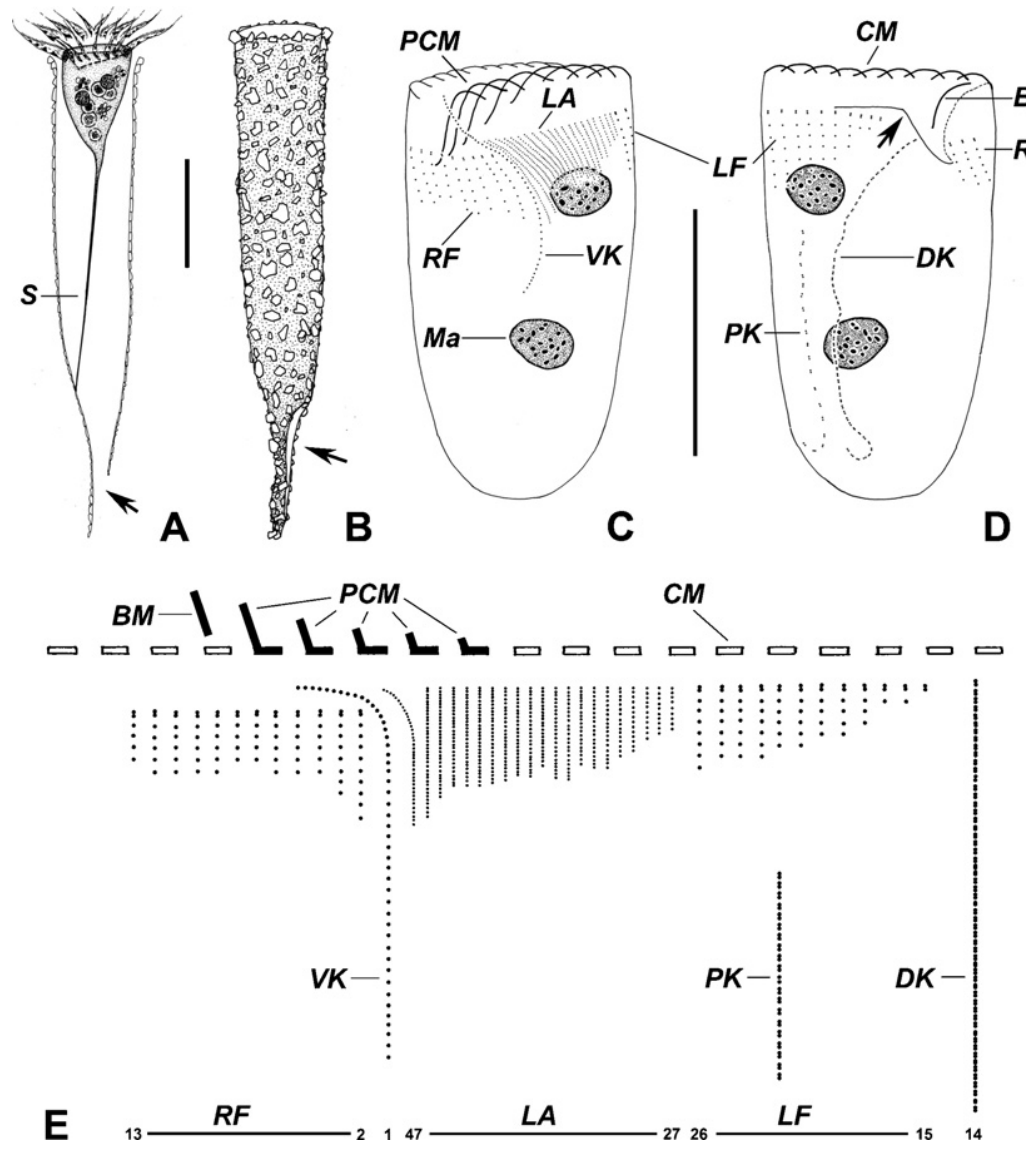

Fig. 4. A-E. Tintinnopsis radix from life (A, B) and after protargol impregnation (C-E). A, B. Lateral view of an extended specimen, arrow indicates the gap at the posterior end. C, D. Ciliary pattern of ventral (C) and dorsal (D) side, arrow shows the endoral membrane. E. Kinetal map of a morphostatic specimen. BM, buccal membranelle; CM, collar membranelles; DK, dorsal kinety; LA, lateral ciliary field; LF, left ciliary field; Ma, macronuclear nodules; PCM, prolonged collar membranelles; PK, posterior kinety; RF, right ciliary field; S, stalk; VK, ventral kinety. Scale bars $=50 \mu \mathrm{m}$.

or third kinety of right ciliary field, consisting of about 48 monokinetids. On average 12 kineties in right and 13 in left ciliary field, all composed of monokinetids with one anterior dikinetid. Lateral ciliary field comprises about 20 monokinetidal kineties. About 56 dikinetids in dorsal kinety and 21 in posterior kinety. On average 19 collar membranelles five of which extend into buccal cavity; one buccal membranelle.

\section{Deposition of voucher slides}

One voucher slide (No. YJP07091101) with protargolimpregnated specimens is deposited at the Laboratory of Protozoology, Institute of Evolution and Marine Biodiversity, Ocean University of China, Qingdao. A second voucher slide with protargol-impregnated specimens is deposited in the Natural History Museum, London, UK with Registration No. NHMUK 2011.8.25.2.

\section{Description of specimens from the Jiaozhou Bay population}

Lorica conspicuously elongated and narrow, 190-340 $\mu \mathrm{m}$ long and $35-70 \mu \mathrm{m}$ wide, with long anterior cylinder, posterior cone narrowing gradually to pedicel which often has an opening near tip (Figs 3A, 4A, B). Lorica wall thin, agglomerated with mineral particles.

Cell obconical (Figs 3A, B, 4A). Posterior end narrowed and always forming a stalk, which attached to tapered portion of lorica (Fig. 4A). Cortex fragile and cell easily bursting. Cell retracting quickly into lorica with its contractile stalk and posterior portion when being disturbed. Neither contractile vacuole nor cytopyge observed (Fig. 3A, B). Accessory combs, striae, tentaculoids, and capsules not recognized.

Buccal cavity relatively shallow and inconspicuous. Buccal apparatus consisting of 18-20 collar membranelles with cilia about $30 \mu \mathrm{m}$ long, including five prolonged collar membranelles and one buccal membranelle (Figs 3C, E, 4C-E). Buccal membranelle separated from prolonged collar membranelles and closed to endoral membrane (Figs 3C, 4D). Endoral membrane composed of a single row of ciliated monokinetids and located on right side of oral groove (Figs 3C, E, 4D).

Two ellipsoidal to ovoidal macronuclear nodules, 8-20 $\mu \mathrm{m} \times 5-12 \mu \mathrm{m}$, one each in anterior and posterior 

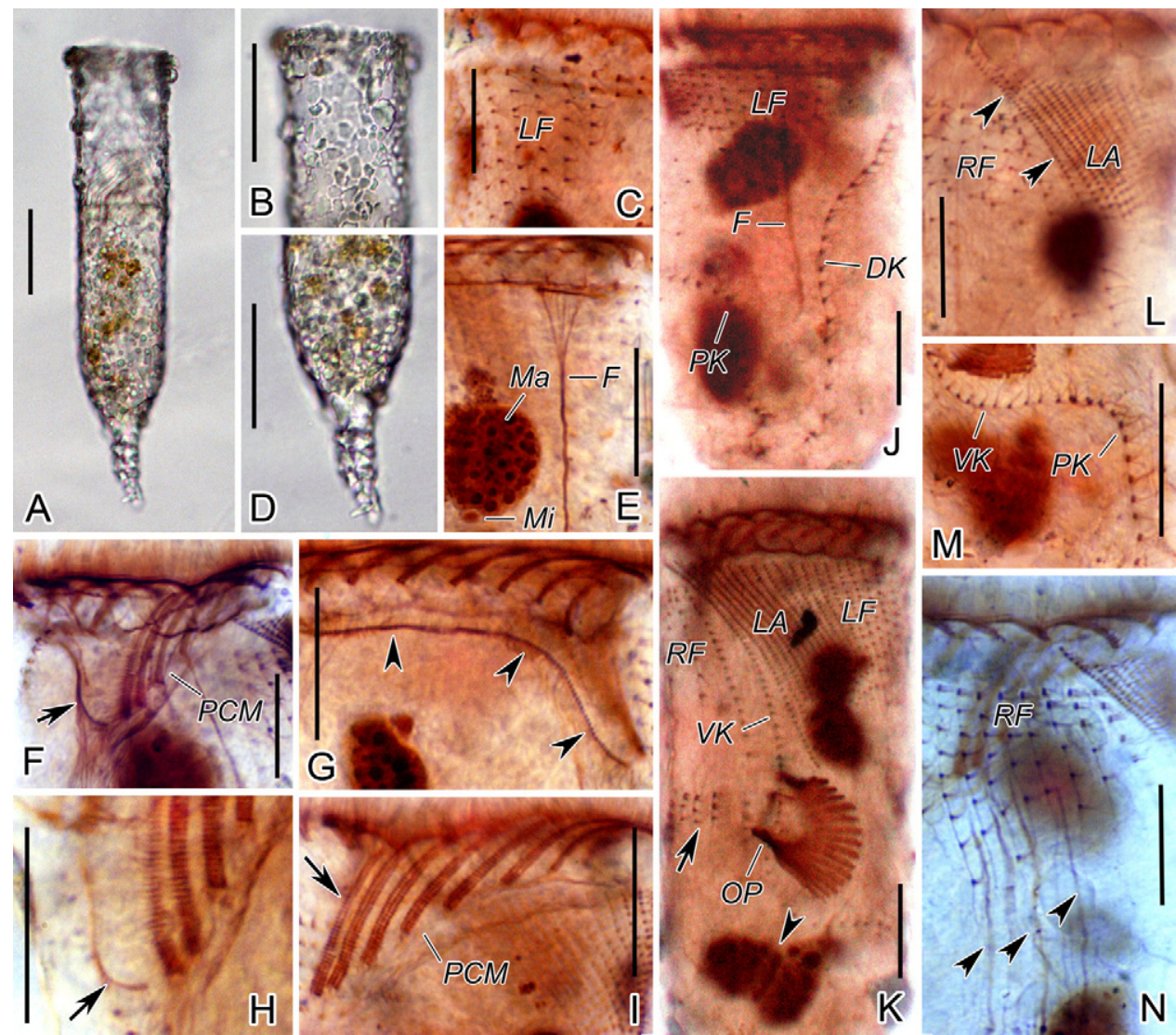

Fig. 5. A-N. Tintinnopsis cylindrica from life (A, B, D) and after protargol impregnation (C, E-N). A. Lateral view of the cylindroidal portion. B. The lorica wall with many silt particles. C, J. Ciliary pattern of dorsal side. D. Lorica, tapered portion. E. Fibres associated with the oral ciliature. F-I. Oral zone. K. Ventral view of a middle divider showing that the new oral apparatus develops in a subsurface pouch posterior to proter's lateral ciliary field, arrow marks the opisthe's right ciliary field, arrowhead shows the macronuclear reorganization band. L. Ciliary pattern of ventral side, arrowheads show the ventral kinety. M. Ventral and posterior kineties. N. Arrowheads indicate the fibres associated with somatic ciliature. DK, dorsal kinety; F, fibrillar structures; LA, lateral ciliary field; LF, left ciliary field; Ma, macronuclear nodules; Mi, micronucleus; OP, oral primordium; PCM, prolonged collar membranelles; PK, posterior kinety; RF, right ciliary field; VK, ventral kinety. Scale bars $=40 \mu \mathrm{m}(\mathrm{A}, \mathrm{B}, \mathrm{D}) ; 15 \mu \mathrm{m}(\mathrm{C}, \mathrm{E}-\mathrm{N})$.

halves of cell (Fig. 3I). Two micronuclei, one closely associated with each macronuclear nodule.

Somatic ciliary pattern comprising ventral, dorsal, and posterior kineties as well as right, left, and lateral ciliary fields (Figs 3G, H, 4C-E). Ventral kinety commencing about $15 \mu \mathrm{m}$ anterior to third or fourth kinety of right ciliary field, composed of 34-68 ciliated monokinetids, anterior kinetosomes closely spaced (Figs 3F, 4C, E). Dorsal kinety composed of 40-70 dikinetids with only posterior kinetosome ciliated, commencing 1-2 $\mu \mathrm{m}$ posterior to the endoral membrane, about $8 \mu \mathrm{m}$ from left and $15 \mu \mathrm{m}$ from right ciliary fields respectively, extending on left dorsal side and terminating near posterior end of cell (Figs 3D, K, 4D). Posterior kinety composed of 16-28 closely spaced dikinetids with only the posterior kinetosome ciliated; commencing $5 \mu \mathrm{m}$ anteriorly below left ciliary field and extending posteriad parallel to dorsal kinety (Figs 3H, 4D, E). Right and left ciliary fields commencing about $8 \mu \mathrm{m}$ and $5 \mu \mathrm{m}$ behind collar membranelles respectively, 2-15 $\mu \mathrm{m}$ long, each with $12-14$ somatic kineties
(Figs 3D, F, 4C, D). Each of these somatic kineties comprising densely arranged monokinetids with one dikinetid at anterior end (Fig. 4E). Kineties in lateral ciliary field commencing about $5 \mu \mathrm{m}$ behind collar membranelles, composed of 19-24 ciliated kinetids, 8-20 $\mu \mathrm{m}$ long, anterior kinetids typically closely spaced, leftmost kineties with more widely spaced ciliated kinetids, the rightmost kinety extending parallel to the distinctly curved ventral kinety (Fig. 3F, $\mathrm{G}, \mathrm{K})$.

\section{Cell division}

Only few sufficiently impregnated dividers were found (Fig. 3J, K). Oral primordium is located posterior to the lateral ciliary field (Fig. 3J, K). The ventral kinety curves along the right margin of the oral primordium (Fig. 3K). One replication band each traverses the macronuclear nodules (Fig. 3J).

\section{Ecological features}

Water temperature $13{ }^{\circ} \mathrm{C}$, salinity about $30 \%$ o, pH about 8 . 

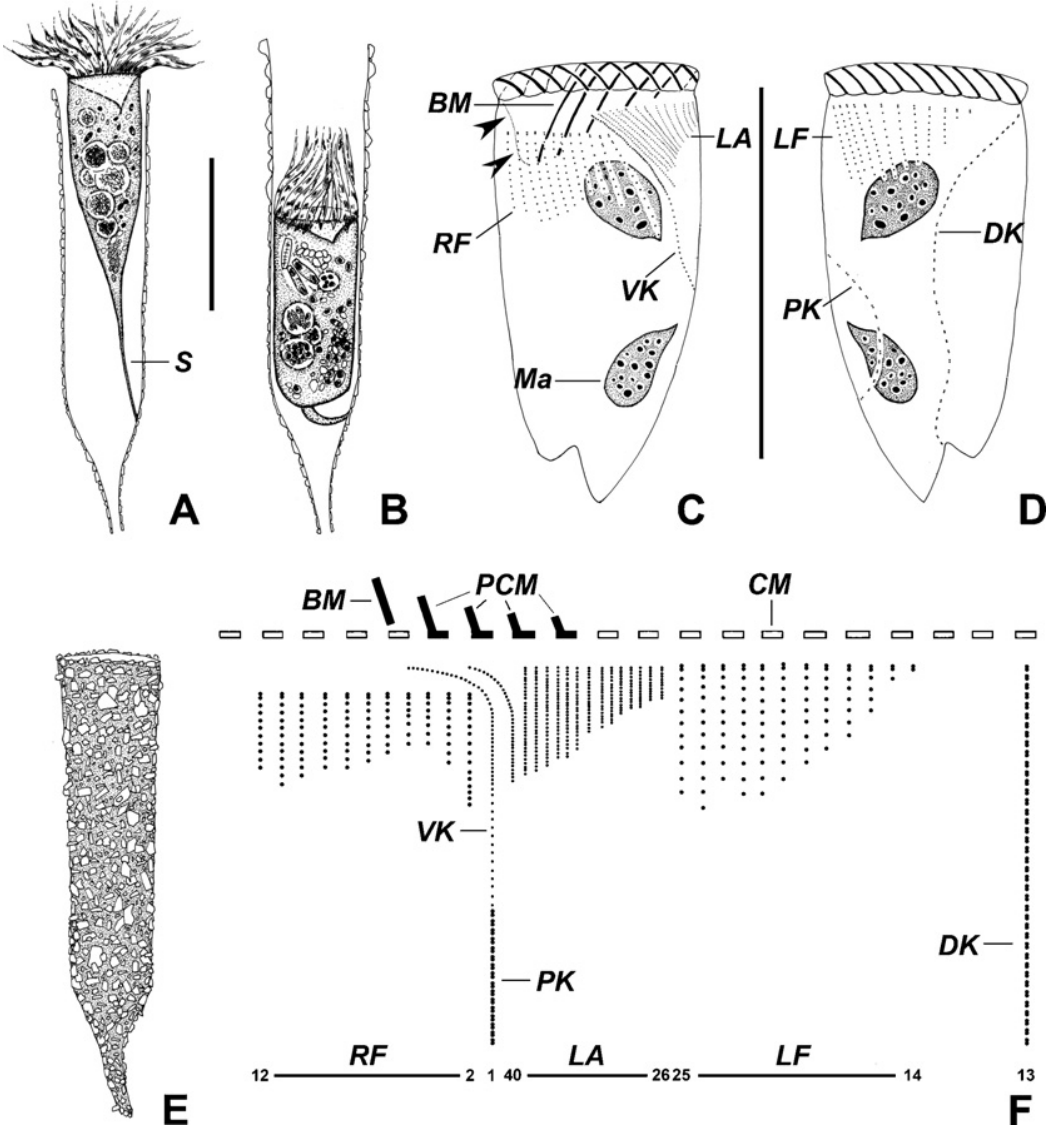

Fig. 6. A-F. Tintinnopsis cylindrica from life (A-C) and after protargol impregnation (D-F). A. Lateral view of an extended specimen. B. Contracted cell. C, D. Ciliary pattern of ventral (D) and dorsal (E) side, arrowheads show the endoral membrane. E. Lorica. F. Kinetal map of a morphostatic specimen. BM, buccal membranelle; CM, collar membranelles; DK, dorsal kinety; LA, lateral ciliary field; LF, left ciliary field; Ma, macronuclear nodules; PCM, prolonged collar membranelles; PK, posterior kinety; RF, right ciliary field; S, stalk; VK, ventral kinety. Scale bars $=50 \mu \mathrm{m}$.

\section{Comparison and remarks}

Although Tintinnopsis radix has been reported several times over the past 80 years (Durán 1953; Kofoid and Campbell 1929; Marshall 1969; Paulmier 1995), its cell features had never been disclosed. Based on previous and current detailed observation, an improved diagnosis is presented here.

Tintinnopsis radix was first reported by Imhof (1886) under the basionym Codonella radix, and redescribed by Brandt (1907) who transferred it to Tintinnopsis Stein, 1867. Tintinnopsis radix was subsequently reported on several occasions (e.g., Balech 1959; Dolan 1991; Durán 1953; Gold and Morales 1976; Kofoid and Campbell 1929; Marshall 1969; Paulmier 1995, 1997; Pierce and Turner 1994; Tregouboff 1957; Xu and Song 2005) and in all cases it is characterized by its lorica morphology. The lorica of the Chinese population matches the original description (Imhof 1886) well in shape; however, it is shorter $(192-336 \mu \mathrm{m}$ vs. up to $480 \mu \mathrm{m})$ and has a wider oral diameter $(54 \mu \mathrm{m}$ vs. $48 \mu \mathrm{m})$. In comparison with further populations, its size falls well within the range recorded, such as lorica length $182-524 \mu \mathrm{m}$ although a little wider $(36-72 \mu \mathrm{m}$ vs. 30-53 $\mu \mathrm{m})$ in diameter (Balech 1959; Kofoid and Campbell 1929; Marshall 1969; Paulmier 1997). Accordingly, its identity is not in doubt.

\section{Tintinnopsis cylindrica Daday, 1887 (Figs 5A-N, 6A-F; Table 1)}

This widely distributed organism was redefined and neotypified by Agatha and Riedel-Lorjé (2006) based on a German population. The Chinese population corresponds well with the German one.

\section{Deposition of voucher slides}

One voucher slide (No. YJP07051501) with protargolimpregnated specimens is deposited in the Laboratory of Protozoology, Institute of Evolution and Marine Biodiversity, Ocean University of China, Qingdao. A second voucher slide with protargol-impregnated specimens is deposited in the Natural History Museum, London, UK with Registration No. NHMUK 2011.8.25.3. 


\section{Description of Chinese population}

Lorica 135-180 $\mu \mathrm{m}$ long, aperture $45-50 \mu \mathrm{m}$ wide, posteriorly tapered, merging into straight cylindroidal process about $20 \mu \mathrm{m}$ long and 10-15 $\mu \mathrm{m}$ wide (Figs 5A, 6A-C).

Cells elongate obconical and highly contractile (Figs 5A, 6A, B). Posterior end narrowed and always forming a short stalk, with which cell adheres to inside of lorica (Fig. 6A, B).

Two macronuclear nodules, $8-22 \mu \mathrm{m} \times 8-15 \mu \mathrm{m}$, possessing many large nucleoli. Two micronuclei each closely associated to one of the macronuclear nodules (Fig. 5E).

About 20 collar membranelles, including one buccal membranelle and four prolonged collar membranelles (Fig. 5I). Endoral membrane comprising a single row of ciliated monokinetids, located on right side of oral groove (Figs 5F-H, 6C).

Somatic ciliature composed of one ventral, one posterior, and one dorsal kinety (Figs 5J-M, 6D-F). Ventral kinety with 44-67 monokinetids (Fig. 5M), dorsal kinety with 30-56 closely spaced dikinetids (Fig. 5J), and posterior kinety with 10-19 closely spaced dikinetids (Figs 5J, 6E).

Kineties in right and left ciliary fields composed of monokinetids with a dikinetid at anterior end, whereas kineties of lateral ciliary field entirely monokinetid (Figs 5C, K, L, N, 6D-F). Right ciliary field composed of 10-12 kineties of different length, the leftmost kinety being conspicuously long (Figs 5K, L, 6D, F). Left ciliary field consists of 11 or 12 kineties (Figs 5C, J, 6E, F). Lateral ciliary field with 13-16 monokinetid kineties that become shorter and more closely spaced and shorter from left to right (Figs 5K, L, 6D, F).

\section{Ecological features}

Water temperature about $8{ }^{\circ} \mathrm{C}$, salinity about $31 \%$ o, $\mathrm{pH}$ 8.4.

\section{Comparison and remarks}

Tintinnopsis cylindrica was first reported under the name Tintinnopsis davidoffii var. cylindrica Daday, 1887. Wright (1907) raised it to species rank. Agatha and Riedel-Lorjé (2006) supplied the details of the cell morphology, firstly reported its ciliary pattern based on a population from Germany, and also established a neotype. The Chinese population closely resembles both the population studied by Daday (1887) and the neotype in terms of the size and shape of the lorica. Furthermore, the somatic ciliary pattern and the oral apparatus correspond with those of the neotype, although the Chinese population has fewer posterior kinetids (10-19 vs. 15-45) (Agatha and Riedel-Lorjé 2006).

\section{Acknowledgements}

This work was supported by the Natural Science Foundation of China (Projects Nos. 31071893 and 31030059), the research group project No. RGP-VPP-083, King Saud
University Deanship of Scientific Research, Saudi Arabia, and the Royal Society Joint Projects scheme. We thank Prof. Xiaozhong $\mathrm{Hu}$ and Dr. Weiwei Liu, OUC, for their great helps in preparing the draft. We also greatly appreciate the comments of two anonymous reviewers and the editor, Dr. Helmut Berger, who helped to improve our manuscript significantly.

\section{References}

Agatha, S., 2008. Redescription of the tintinnid ciliate Tintinnopsis fimbriata Meunier 1919 (Spirotricha, Choreotrichida) from coastal waters of northern Germany. Denisia 23, 261-272.

Agatha, S., 2010a. Redescription of Tintinnopsis parvula Jörgensen, 1912 (Ciliophora: Spirotrichea: Tintinnina), including a novel lorica matrix. Acta Protozool. 49, 213-234.

Agatha, S., 2010b. A light and scanning electron microscopic study of the closing apparatus in tintinnid ciliates (Ciliophora, Spirotricha, Tintinnina): a forgotten synapomorphy. J. Eukaryot. Microbiol. 57, 297-307.

Agatha, S., 2011. Updated hypothesis on the evolution of oligotrichid ciliates (Ciliophora, Spirotricha, Oligotrichida) based on somatic ciliary patterns and ontogenetic data. Eur. J. Protistol. $47,51-56$.

Agatha, S., Riedel-Lorjé, J.C., 2006. Redescription of Tintinnopsis cylindrica Daday, 1887 (Ciliophora: Spirotricha) and unification of tintinnid terminology. Acta Protozool. 45, 137-151.

Agatha, S., Strüder-Kypke, M.C., 2007. Phylogeny of the order Choreotrichida (Ciliophora, Spirotricha, Oligotrichea) as inferred from morphology, ultrastructure, ontogenesis, and SSrRNA gene sequences. Eur. J. Protistol. 43, $37-63$.

Agatha, S., Tsai, S.F., 2008. Redescription of the tintinnid Stenosemella pacifica Kofoid and Campbell 1929 (Ciliophora, Spirotricha) based on live observation, protargol impregnation, and scanning electron microscopy. J. Eukaryot. Microbiol. 55, $75-85$.

Balech, E., 1948. Tintinnoinea de Atlantida (R. O. del Uruguay). Comun. Mus. argent. Cienc. nat. Bernardino Rivadavia, Serie Ciencias Zool. 7, 1-23.

Balech, E., 1959. Tintinnoinea de Mediterraneo. Trab. Inst. Esp. Oceanogr. 28, 1-88.

Brandt, K., 1906. Die Tintinnodeen der Plankton-Expedition. Tafelerklärungen nebst kurzer Diagnose der neuen Arten. Ergebn. Plankton-Exped. Humboldt-Stiftung 3 La, 1-33, Tafeln $1-70$.

Brandt, K., 1907. Die Tintinnodeen der Plankton Expedition Systematischer Teil. Ergebn. Plankton-Exped. Humboldt-Stiftung 3 La, 1-488.

Choi, J.K., Coats, D.W., Brownlee, D.C., Small, E.B., 1992. Morphology and infraciliature of three species of Eutintinnus (Ciliophora; Tintinnina) with guidelines for interpreting protargol-stained tintinnine ciliates. J. Protozool. 39, 80-92.

Cosper, T.C., 1972. The identification of tintinnids (Protozoa: Ciliate: Tintinnida) of the St. Andrew Bay system Florida. Bull. Mar. Sci. 22, 391-418. 
Daday, E.V., 1887. Monographie der Familie der Tintinnodeen. Mitt. Zool. Stn Neapel 7, 473-591.

Dolan, J.R., 1991. Guilds of ciliate microzooplankton in the Chesapeake Bay. Estuar. Coast. Shelf Sci. 33, 137-153.

Durán, M., 1953. Contribución al estudio de los Tintinnidos del plancton de las costas de Castellón (Mediterráneo occidental). Nota II. Publ. Inst. Biol. Appl. 12, 79-95.

Foissner, W., Wilbert, N., 1979. Morphologie, Infraciliatur und Ökologie der limnischen Tintinnina: Tintinnidium fuviatile Stein, Tintinnidium pusillum Entz, Tintinnopsis cylindrata Daday und Codonella cratera (Leidy) (Ciliophora Polyhymenophora). J. Protozool. 26, 90-103 (with English summary).

Gao, S., Gong, J., Lynn, D., Lin, X., Song, W., 2009. An updated phylogeny of oligotrich and choreotrich ciliates (Protozoa, Ciliophora, Spirotrichea) with representative taxa collected from China seas. Syst. Biodivers. 7, 235-242.

Gold, K., Morales, E.A., 1976. Studies on the sizes, shapes and the development of the lorica of agglutinated Tintinnida. Biol. Bull. Mar. Biol. Lab. 150, 377-392.

Imhof, O.E., 1886. Über microscopische pelagische Thiere aus den Lagunen von Venedig. Zool. Anz. 9, 101-104.

Jiang, Y., Xu, H., Hu, X., Zhu, M., Al-Rasheid, K.A.S., Warren, A., 2011a. An approach to analyzing spatial patterns of planktonic ciliate communities for monitoring water quality in Jiaozhou Bay, northern China. Mar. Pollut. Bull. 62, 227-235.

Jiang, Y., Xu, H., Al-Rasheid, K.A.S., Warren, A., Hu, X., Song, W., 2011b. Planktonic ciliate communities in a semi-enclosed bay of Yellow Sea, northern China: annual cycle. J. Mar. Biol. Assoc. U. K. 91, 97-105.

Kim, Y., Kim, S.Y., Lee, W., Choi, J.K., 2010. New observations on the choreotrich ciliate Strombidinopsis acuminata FauréFremiet, 1924, and comparison with Strombidinopsis jeokjo Jeong et al., 2004. J. Eukaryot. Microbiol. 57, 48-55.

Kofoid, C.A., Campbell, A.S., 1929. A conspectus of the marine and fresh-water Ciliata belonging to the suborder Tintinnoinea, with descriptions of new species principally from the Agassiz Expedition to the eastern tropical Pacific 1904-1905. Univ. Calif. Publ. Zool. 34, 1-403.

Kofoid, C.A., Campbell, A.S., 1939. Reports on the scientific results of the expedition to the eastern tropical Pacific, in charge of Alexander Agassiz, by the U. S. Fish Commission Steamer "Albatross," from October, 1904, to March, 1905, Lieut.Commander L. M. Garrett, U. S. N. Commanding. XXXVII. The Ciliata: the Tintinnoinea. 84. Bull. Mus. Comp. Zool. Harvard, $1-473$.

Laackmann, H., 1913. Adriatische Tintinnodeen. Sber. Akad. Wiss. Wien, Math. Nat. K1 122, 123-167.

Laval-Peuto, M., 1994. Classe des Oligotrichea Bütschli, 1887. Ordre des Tintinnida Kofoid et Campbell 1929. In: de Puytorac, P. (Ed.), Traité de Zoologie. Anatomie, Systématique, Biologie. II. Infusoires Ciliés. 2. Systématique, Masson, Paris, Milano, Barcelona, pp. 181-219.

Liu, W., Xu, D., Lin, X., Li, J., Gong, J., Al-Rasheid, K.A.S., Song, W., 2009. Novistrombidium sinicum n. sp. and Novistrombidium orientale $\mathrm{n}$. sp. (Protozoa: Ciliophora): two new oligotrich ciliates from a mangrove wetland, South China. J. Eukaryot. Microbiol. 56, 459-465.
Liu, W., Yi, Z., Lin, X., Al-Rasheid, K.A.S., 2011a. Morphologic and molecular data suggest that Lynnella semiglobulosa $\mathrm{n}$. g., n. sp. represents a new family within the subclass Choreotrichia (Ciliophora, Spirotrichea). J. Eukaryot. Microbiol. 58, 43-49.

Liu, W., Yi, Z., Warren, A., Al-Rasheid, K.A.S., Al-Farraj, S.A., Lin, X., Song, W., 2011b. Taxonomy, morphology and molecular systematics of the new oligotrich ciliate, Williophrya maedai gen. nov., sp. nov., with redescriptions of Strombidium basimorphum Martin and Montagnes 1993 and Pseudotontonia simplicidens (Lynn and Gilron, 1993) Agatha, 2004 (Protozoa, Ciliophora, Oligotrichia). Syst. Biodivers. 9, 247-258.

Lynn, D.H., 2008. The Ciliated Protozoa. Characterization Classification, and Guide to the Literature, 3rd ed. Springer, Dordrecht.

McManus, B.G., Xu, D., Costas, A.B., Katz, A.L., 2010. Genetic identities of cryptic species in the Strombidium stylifer/apolatum/oculatum cluster, including a description of Strombidium rassoulzadegani n. sp. J. Eukaryot. Microbiol. 57, 369-378.

Marshall, S.M., 1969. Protozoa, Order: Tintinnida, Family: Tintinnidiidae, Genus: Tintinnidium, Family: Codonellidae Genus: Tintinnopsis. In: Fraser, J.H., Hansen, V.K. (Eds.), Fiches d'identifcation du zooplankton. Conseil Permanent International pour l'Exploration de la Mer. Charlottenlund slot-Denmark, pp. 117-127.

Paulmier, G., 1995. Les tintinnides (Ciliophora, Oligotrichida, Tintinnida) des côtes françaises de la Manche et de l'Atlantique. Ann. Soc. Sci. Nat. Charente-Maritimeg 8, 453-487.

Paulmier, G., 1997. Tintinnides (Ciliophora, Oligotrichida, Tintinnina) de l'Atlantique Boréal, de l'Océan Indien et quelques mers adjactentes: Méditerranée, Mer Caraibe, Mer Rouge. Inventaire et distribution. Observations basée sur les loricas. Station IFREMER DRV/RH/97-17, pp. 1-126.

Petz, W., Foissner, W., 1993. Morphogenesis in some freshwater tintinnids (Ciliophora, Oligotrichida). Eur. J. Protistol. 29, 106-120.

Petz, W., Song, W., Wilbert, N., 1995. Taxonomy and ecology of the ciliate fauna (Protozoa, Ciliophora) in the endopagial and pelagial of the Weddell Sea, Antarctica. Stapfia 40, 1-223.

Pierce, R.W., Turner, J.T., 1992. Ecology of planktonic ciliates in marine food webs. Rev. Aquat. Sci. 6, 139-181.

Pierce, R.W., Turner, J.T., 1993. Global biogeography of marine tintinnids. Mar. Ecol. Prog. Ser. 94, 11-26.

Pierce, R.W., Turner, J.T., 1994. Plankton studies in Buzzards Bay, Massachusetts, USA. IV. Tintinnids, 1987 to 1988. Mar. Ecol. Prog. Ser. 112, 235-240.

Rychert, K., 2010. Dependence between volumes of protoplast and lorica in Lugol-fixed tintinnid ciliates. Protist 162, 249-252.

Song, W., Wilbert, N., 1995. Benthische Ciliaten des Süßwassers. In: Röttger, R. (Ed.), Praktikum der Protozoologie. Gustav Fischer Verlag, New York, pp. 156-168.

Tregouboff, G.R.M., 1957. Manuel de planctonologie méditerranéanne, vol. 2. Centre National de la Recherche Scientifique Ed., Paris, pp. 1-592.

Tsai, S., Chen, J., Chiang, K., 2010. Spirotontonia taiwanica n. sp. (Ciliophora: Oligotrichida) from the coastal waters of Northeastern Taiwan: morphology and nuclear small subunit rDNA sequence. J. Eukaryot. Microbiol. 57, 429-434.

Wright, R.R., 1907. The plankton of eastern Nova Scotia waters: an account of floating organisms upon which young food-fishes 
mainly subsist. Ann. Rep. Dept. Mar. Fish. Fish. Branch Ottawa $39,1-18$.

Xu, D., Song, W., 2005. Tintinnid ciliates from Qingdao (Protozoa, Ciliophora, Tintinnida). Acta Zootaxon. Sin. 30, 501-508 (in Chinese with English abstract).

Zhang, Q., Yi, Z., Xu, D., Al-Rasheid, K.A.S., Gong, J., Song, W., 2010. Molecular phylogeny of oligotrich genera
Omegastrombidium and Novistrombidium (Protozoa, Ciliophora) for the systematical relationships within family Strombidiidae. Chinese J. Oceanol. Limnol. 28, 769-777.

Zhang, W., Wang, R., 2000. Summertime ciliate and copepod nauplii distributions and microzooplankton herbivorous activity in the Laizhou Bay, Bohai Sea China. Estuar. Coast. Shelf Sci. 51, 103-114. 